\title{
Virulence factors os Escherichia coli: an overview of human and animal infections with emphasis in bovine mastitis
}

\section{Fatores de virulência de Escherichia coli: revisão de infecções em humanos e animais com ênfase na mastite bovina}

\author{
Simony Trevizan Guerra ${ }^{1 *}$; Carolina Lechinski de Paula ${ }^{1}$; Carmen Alicia Daza \\ Bolaños$^{2}$; Rodrigo Tavanelli Hernandes ${ }^{3}$; Márcio Garcia Ribeiro ${ }^{4}$
}

\begin{abstract}
Escherichia coli (E. coli) is a normal inhabitant of the enteric microflora of human and animal. Intestinal and extra-intestinal infections caused by $E$. coli in mammals are characterized by the presence of diversity of virulence factors. In addition it can be isolated from environment surrounding human and animal farms. E. coli is the main pathogen causing clinical mastitis from environmental origin in dairy cattle. It causes a wide range of disease severity, from changes seen exclusively in milk to severe systemic signs. The severity of clinical mastitis has been conventionally classified into three levels: mild (grade 1), moderate (score 2), and severe (score 3). Recently, reports of cases of bovine mastitis caused by environmental agents has increased, in particular in countries with success in control contagious microorganisms. Unlike enteric and certain extra-enteric conditions in domestic animals and humans, the impact of virulence factors on the occurrence of bovine mastitis due to E. coli, as well as the clinical severity of the cases, is not fully understood. In this regard, the present study reviewed the most relevant virulence factors of $E$. coli in human and animals, with emphasis in bovine mastitis.
\end{abstract}

Key words: Mammary gland. Virulence properties. Coliform mastitis.

\section{Resumo}

Escherichia coli (E. coli) é um micro-organismo que pertence a microbiota entérica de humanos e animais. As afecções entéricas e extra-entéricas causadas por E.coli em mamíferos são caracterizadas pela presença de ampla diversidade de fatores de virulência. Além disso, este micro-organismo também pode ser isolado em ambientes de produção animal. E. coli é o principal agente ambiental que causa mastite clínica em vacas leiteiras, provocando sinais clínicos que podem variar desde mudanças observadas exclusivamente no leite até sinais sistêmicos graves. A gravidade da mastite clínica é convencionalmente classificada em três níveis: leve (grau 1), moderada (grau 2), e grave (grau 3). Atualmente, os relatos de casos de mastite bovina causada por agentes ambientais têm aumentando, principalmente nos países que conseguiram controlar os micro-organismos contagiosos. Diferentemente de infecções entéricas e certas extra-entéricas em humanos e animais, o impacto dos fatores de virulência de E. coli na ocorrência

1 Discentes, Pós-Graduação em Medicina Veterinária, Universidade Estadual Paulista, UNESP, Botucatu, SP, Brasil. E-mail: simony.guerra@gmail.com; ca_lechinski@yahoo.com.br

2 Prof ${ }^{a}$, Faculdade de Medicina Veterinária e Zootécnica, Universidade Antônio Nariño, Popayán, Cauca, Colômbia. E-mail: carmen.dazab@hotmail.com

3 Prof, Instituto de Biociências, IBB, Universidade Estadual Paulista, UNESP, Botucatu, SP, Brasil. E-mail: rt.hernandes@unesp. br

4 Prof., Faculdade de Medicina Veterinária e Zootecnia, Universidade Estadual Paulista, UNESP, Botucatu, SP, Brasil. E-mail: marcio.ribeiro@unesp.br

* Author for correspondence 
de mastite bovina não é totalmente compreendido, assim como na gravidade clínica dos casos. Neste contexto, o presente estudo revisou os fatores de virulência de $E$. coli mais relevantes para humanos e animais, com ênfase na mastite bovina.

Palavras-chave: Glândula mamária. Mecanismos de virulência. Mastite por coliformes.

\section{General Characteristics of Bovine Mastitis by Escherichia coli}

Mastitis is an inflammatory process involving the mammary gland parenchyma, and characterized by physical, chemical, and cellular changes to milk, in addition to the pathological alterations in the glandular tissue. It is one of the most complex disease and cause important economic losses affecting the dairy industry due to reduced milk production and quality, disposal of the milk with antimicrobial residues from treated animals, loss of mammary quarters, early culling of animals, as well as expenses on veterinary services and drugs (BRADLEY, 2002). Clinical mastitis is the most frequent disease in dairy cattle, affecting between 23 to $40 \%$ of milking cows (RUEGG, 2017). In Brazil it is estimated that $35 \%$ of clinical cases in dairy cows are due to coliforms (OLIVEIRA et al., 2015).

Mastitis is traditionally classified as clinical or subclinical. Clinical mastitis occurs when changes occur in the milk (presence of lumps, pus, and blood streaks) and mammary gland (edema, hyperthermia, hyperemia, hardening, nodules, pain). Moreover, some animals may present systemic signs such as inappetence, fever, tachycardia, tachypnea, decubitus, decreased ruminal movements and occasionally death. The clinical cases of mastitis in cows usually involving microorganisms that cause environmental mastitis such as Enterobacteriaceae goup (Escherichia coli, Klebsiella pneumoniae, Enterobacter sp., Serratia sp., Proteus sp.), Pseudomonas sp., fungi and algae. On the other hand, subclinical mastitis is characterized by changes only in milk composition and quality (BRADLEY, 2002).
E. coli is the main microorganism causing bovine clinical mastitis of environmental origin. Clinical signs range from changes exclusively observed in milk to severe systemic signs. The clinical severity of bovine mastitis has been conventionally classified into three levels: mild (score 1), moderate (score 2), and severe (score 3). About 50 to $90 \%$ of clinical cases are classified as mild, with changes observed exclusively in the milk. Moderate cases occours between 10 to $40 \%$ of cases, involving abnormalities in the milk as well as clinical signs of inflammation in the mammary gland. Severe cases are not common ( $<20 \%$ of cases) and shows signs in the milk, mammary gland, and significant systemic signs, including rumen stasis, dehydration, and even death due to endotoxic or septic shock (WENZ et al., 2001, 2006).

Despite reports about enteric and some extraenteric conditions in domestic animals, the profile and impact of virulence factors (VF) on bovine mastitis caused by E. coli or in the clinical severity have not been fully elucidated. Clinical severity can be attributed in part to the systemic action of bacterial LPS (induction of inflammation and endotoxic shock); low immune response of certain hosts, or even the opportunistic nature of the pathogen (SUOJALA et al., 2011).

Considering wide diversity of $E$. coli virulence properties in human and animal infections, the negative impact of mastitis on dairy farms, increase in the environmental microorganisms in farms that controlled contagious microorganisms, and poor understanding about the influence of these VF in the establishment and clinical severity of cases, the present study reviewed the main virulence properties of human and animal infections by $E$. coli, with emphasis on bovine mastitis. 


\section{E. coli: Characteristics and Virulence Properties}

E. coli was first isolated in 1885 , as described by Theodor Escherich (1893), from the feces of children. It was first isolated from domestic animals in 1893, from calves suffering from diarrhea. Them, different diseases were attributed to this pathogen; in fact, it is one of the most studied microorganisms in human and veterinary medicine. E. coli belongs to the Entetobacteriacea family. This pathogen is a facultative anaerobic Gram-negative cocobacillus, found in the enteric microflora of mammals. Some isolates are pathogenic to human or animals. The pathogenic nature of $E$. coli is strongly associated with multiple VFs, which determine enteric and extra-enteric infections (CROXEN; FINLAY, 2010).

Diarrheogenic E. coli (DEC) strains are divided into different pathotypes, based on the production of toxins, specific VF, invasive ability, and clinical manifestations in hosts. Classically, diarrheogenic pathogens are classified as follows: enterotoxigenic E. coli (ETEC), enteropathogenic (EPEC), enteroinvasive (EIEC), shiga toxin-producing E. coli (STEC), enteroaggregative (EAEC), and diffusely adherent (DAEC) (CROXEN; FINLAY, 2010). E. coli isolates related to extraintestinal infections (ExPEC) can cause various clinical manifestations in both humans and animals (RIBEIRO et al., 2016). Among ExPEC, the most studied isolates are those related to neonatal meningitis (NMEC - neonatal meningitis E. coli) and uropathogenic conditions (UPEC - uropathogenic E. coli) in humans (KAPER; NATARO; MOBLEY, 2004). Another important ExPEC is related to large economic losses in the poultry industry, called avian pathogenic E. coli (APEC). It causes multiple systemic infections in birds, often referred to as colibacillosis. In addition, a specific $E$. coli pathotype related to bovine mastitis (MPEC) was proposed, although the specific profile of the VF present in these isolates is poorly understood (SHPIGEL et al., 2008).
ExPEC isolates can potentially infect any organ or extra-enteric tissue in animals and humans. Unlike DEC isolates, the VF that define ExPEC (KLEMM et al., 2010) pathotype are not fully understood. In attempt to clarify and better understand what define ExPEC, Johnson et al. (2003) suggest that ExPEC isolates are characterized by the presence of one or more the following genes simultaneously: fimbriae P ( $p a p C$ and/or papG), fimbriae S (sfa/foc), adhesins of the AFA-DR family ( $a f a C$ ), capsular group II capsule ( $k p s M T I I)$, and aerobactin iron uptake system (iucD/iutA). Such findings allowed the postulation of a classification pattern for $E$. coli isolates as ExPEC, irrespective of the site of isolation, which allowed the identification of pathogenic isolates among human or environmental clinical isolates. However, in 50 E.coli isolates obtained from clinical cases of bovine mastitis in Brazil reveled that only one $(2 \%)$ isolate showed more than one gene simultaneously, indicating that this ExPEC identification model appeared to be poorly related to bovine mastitis (GUERRA et al., 2019).

\section{Phylogenetic classification}

The knowledge about a phylogenetic pattern on E. coli isolates has been increasing with modern methods such as sequencing of the bacterial genome. To date, seven phylogenetic groups are described, in which $E$. coli distribution seems to be related to their origin. E. coli isolates can be assignment to seven phylo-groups and clades currently recognized by a quadruplex PCR (CLERMONT et al., 2013). This classification is based on specific genes (chuA, ijaA, $\operatorname{arp} A$ ) and the DNA fragment TspE4.C2. Virulent strains usually belong to phylogroups B2 and D, whereas isolates of groups A and B1 are usually commensal in nature (CLERMONT et al., 2000).

The commensal intestinal strains (groups A or B1) are less pathogenic or rarely harbor VF. On the other hand, diarrheogenic E. coli harboring virulence 
properties such as shiga toxin, adhesins, and able to induce the attaching and effacing lesions, mainly belong to groups A, B1, B2, and D. Virulent strains that cause extraintestinal disorders usually belong to groups B2 and D (CLERMONT et al., 2000). However, the differentiation between commensal and ExPEC isolates is not always possible, even by detection of VF or other molecular epidemiological approaches. Novel mechanisms underlying pathogenicity patterns are constantly being described, and therefore, new studies are required to better understand the VF profile of pathogenic $E$. coli strains causing infections in animals and humans (KOHLER; DOBRINDT, 2011).

\section{Colonization factors or adhesins}

Adhesion is essential for most bacterial pathogens. This process, which allows binding of bacterial cells to host tissue, is mediated by several types of adhesins, which bind to the receptors present on cell membranes (KLEMM; SCHEMBRI, 2000). The adhesins are composed of different adhesive proteins, whose function is to mediate the binding of bacterial cells to specific surface receptors, thus supporting the colonization of both abiotic (plastic and steel) and biotic (target cell) surfaces.

The process of adherence of bacteria to host cells allows the microorganism to resist the host's natural defense mechanisms such as urine flow or peristalsis. Another important function of adhesins is bacterial interaction, necessary for the formation of microcolonies and biofilms (CHAHALES; THANASSI, 2016). The interaction between adhesins and the host cells occurs through receptors; the interactions are of three types: 1) binding between lectins and carbohydrates, 2) interaction between proteins, and 3) hydrophobic bonds between proteins and lipids. Adhesins also allow $E$. coli isolates to colonize and resist in unusual or extraintestinal habitats such as the urinary tract. They form protein structures (fimbriae or pili) that protrude out from the bacterial cell surface and identify receptors on the target cells (KAPER; NATARO; MOBLEY, 2004). In contrast, afimbrial adhesins do not have projections on their surface, and bacterial cells to directly adhere to the target cell surface (LE BOUGUÉNEC, 2005).

\section{Fimbriae}

Fimbria are smaller, thinner, and thicker adhesive structures, present in more numbers than the bacterial flagella. These structures are found in most commensal and pathogenic isolates, wherein they promote the interaction between the microorganism and host receptors (KLINE et al., 2009). Fimbriae may be studied based on the manner of receptor binding; in fact, these are essential VF for most ExPEC isolates. In addition to cell adhesion, fimbriae may perform additional functions such as adhesion to abiotic surfaces, cell aggregation, and biofilm production. The elaboration of fimbriae requires coordinated secretion and ordered assembly of multiple distinct protein subunits. The assembly of fimbriae may occur through different mechanisms such as the Chaperona-Usher system, type IV fimbriae, autotransporter system, and Curli (LE BOUGUÉNEC, 2005).

\section{Type 1 fimbriae}

Type 1 fimbriae is the most frequently occurring adhesive organelle of the family Enterobacteriaceae, found in $>80 \%$ of $E$. coli isolates. It has a tubular and helical structure, composed of the stem, formed by the repetition of several subunits of the major building component called FimA, and other minor fimbrial components: FimF, FimG, and FimH proteins. Structurally, FimG and FimF subunits constitute the bond between FimH and the FimA stem, the sequential orientation being FimA - FimF - FimG - FimH (HAHN et al., 2002). Biosynthesis occurs by the Chaperona-Usher system-assisted assembly, which consists of individual secretion of subunits in the periplasm by the secretory system, 
linked to a chaperone (to prevent premature selfassembly). The chaperone-subunit complex is then directed to the Usher outer membrane protein. Then, the subunit is translocated and incorporated into the growing organelle base (KLEMM; SCHEMBRI, 2000; LE BOUGUÉNEC, 2005).

Type I fimbriae can bind to a wide variety of eukaryotic cells because of the ability of FimH adhesin to recognize mannoside receptors. In addition, FimH is able to promote adhesion in environments with hemodynamic flow forces such as urinary flow, and after adhesion and internalization, it allows the bacterial cells to form intracellular bacterial aggregates (ANDERSON et al., 2003). This could explains the recurrent instances of urinary tract infections in animals and humans, despite antimicrobial treatment (LE BOUGUÉNEC, 2005; MYSOREKAR; HULTGREN, 2006).

Another relevant aspect regard type 1 fimbriae is its role in the initial adhesion to surfaces for biofilm formation which, once formed, may offer selective advantage in vivo under static liquid conditions such as ponds and pools. This is important in case of animals, because the bacteria eliminated in feces can form biofilms on certain surfaces, and consumption of contaminated water by feces can cause infections in a new host (KLEMM; SCHEMBRI, 2004).

\section{P fimbriae}

These are adhesive structures encoded by the pap (pyelonephritis-associated pilus) operon, often associated with the UPEC isolates involved in the diseases of the upper urinary tract in humans. The $\mathrm{P}$ fimbriae recognize glycolipid receptors in the kidneys, contributing to colonization in the uroepithelial cells. Structurally, it is composed of multiple copies of the major protein (PapA) bound to a fibrillar surface comprising the major fibrillar component (PapE) and other minor components (PapF, PapK) and the adesina (PapG) (PROFT; BAKER, 2009).

\section{S fimbriae (S pili)}

$\mathrm{S}$ fimbriae consists of the major adhesive protein $\mathrm{SfaA}$ and three other proteins called $\mathrm{SfaG}$, $\mathrm{SfaH}$, and SfaS. SfaS enables the interaction of the bacterium with host cells (PRASADARAO et al., 1993). It is related to the ability of ExPEC to cause neonatal meningitis. Among the ExPEC strains isolated from intensive care unit (ICU) settings, $\mathrm{S}$ fimbria is the most commonly identified VF in cystitis-causing isolates, suggesting that it confers a selective advantage to the organisms in the lower urinary tract (KLEMM et al., 2010).

\section{Curli}

Curli consist of fine fibers of different sizes, rolled up and aggregated. They appear as a mat of amorphous matrix extending from the cell surface, and have been identified in both E. coli and other Enterobacteriaceae of the genus Salmonella, Shigella, Citrobacter, and Enterobacter. Curli expression is reported in EHEC, ETEC, and other isolates causing sepsis in humans as well as avian infections (PROVENCE; CURTISS, 1992).

These fibers basically constituted by two main proteins: CsgA (forms the majority) and $\mathrm{CsgB}$, the structural component present along the filament in small amounts. Curli fibers are assembled outside the cell through the extracellular nucleation pathway. The CsgA subunit is secreted from the cell and polymerized on the surface, assisted by the nucleating protein $\mathrm{CsgB}$. Another important lipoprotein is $\mathrm{CsgG}$, whose function is to protect $\mathrm{Csg} \mathrm{A}$ and $\mathrm{CsgB}$ from proteolysis, in addition to serving as an assembly platform for Curli (CHAHALES; THANASSI, 2016). Curli expression generally occurs at temperatures below $30^{\circ} \mathrm{C}$ at low osmolarity, although clinical E. coli isolates related to renal infection and sepsis express Curli at $37^{\circ} \mathrm{C}$, indicating a role in pathogenicity (BIAN et al., 2000). 
In addition, Curli has been implicated in several biological processes, including biofilm formation as well as cell aggregation, adhesion and invasion; they act as potent inducers of the host inflammatory response (KLEMM; SCHEMBRI, 2004; PROFT; BAKER, 2009).

\section{Antigen 43}

Antigen 43 (Ag 43) is expressed by several Gram-negative bacteria and is found in most $E$. coli isolates, mainly EPEC and UPEC (KJAERGAARD et al., 2002). It is an autotransporter protein, formed by the two subunits: $\alpha$ and $\beta$. The $\beta$-subunit is an outer membrane component that forms pores, through which the $\alpha$-subunit gains access to the surface of attachment (HENDERSON; NATARO, 2001). Like other adhesins, Ag43 also confers the properties of bacterial aggregation and microcolony formation, which can be considered as the steps preceding biofilm formation (SCHEMBRI et al., 2003).

\section{Type lV fimbriae}

Type IV fimbriae are thin (6-8-nm wide), flexible, and generally form lateral aggregates, thereby generating characteristic bundles. In addition to host cell adhesion and biofilm formation, they have some distinct characteristics such as DNA uptake during transformation, phage transduction, and flagellateindependent movement known as twitching motility (PROFT; BAKER, 2009).

\section{Siderophores}

Iron is an essential element for bacterial metabolism and growth. However, reduced iron concentration in the host tissue pushes the pathogens to develop mechanisms such as exogenous iron uptake or survival at low iron concentrations. For iron exogenous uptake, bacteria such as E. coli possess protein structures called "siderophores," which improve the iron chemotaxis; this is particularly important in extraintestinal infections (HANTKE et al., 2003). Other bacterial strategies to obtain iron include uptake from compounds such as heme, transferrin, and lactoferrin (without siderophores) and the reduction of $\mathrm{Fe} \beta$ to $\mathrm{Fe} \alpha$, with subsequent transport of Fe $\alpha$ (KOSTER, 2001). In humans, some siderophores genes were detected by molecular methods: iron, irp2, iucD, ireA and sitA (JOHNSON et al., 2000; EWERS et al., 2007; RODRIGUEZSIEK et al., 2005). In animals, the presence of VF related to exogenous iron uptake has been described in canine genitourinary tract infections and bovine mastitis (RIBEIRO et al., 2016).

\section{Endotoxins}

Endotoxins are constituents of the outer membrane of Gram-negative bacteria, which, on release, can induce intense pathological effects in hosts. The most commonly endotoxin is lipopolysaccharide(LPS), present on E. coli and other Gram-negative bacteria. LPS is composed of lipid A, core (small number of sugars present in almost all enterobacteria), and $\mathrm{O}$ antigen (oligosaccharide residues that cover the cell and protect it from the action of hydrophobic substances). Also called the somatic antigen, antigen $\mathrm{O}$ is used the base of serogroups determination in E. coli. LPS is released during bacterial multiplication or lysis, and the lipid fraction elicits different levels of inflammatory responses from the host. Lipid A is the biologically active component that determines endotoxic activity and exhibits immunogenic property when exposed to the bacterial surface. The biological effects of lipid A are mediated by the bioactive products derived from macrophages, such as tumor necrosis factor (TNF) (RIETSCHEL et al., 1994).

In the bovine mammary gland, endotoxins are inducers of inflammatory responses, involving intense migration of neutrophils. The release of lipid A is also related to the systemic effects of mastitis, such as fever, dehydration, reduction in 
ruminal movement, and decrease in milk production (BURVENICH et al., 2003; HOGAN; SMITH, 2003). Humans, cattle, equines, pigs, cats, and small ruminants represent the species most sensitive to the effects of bacterial endotoxins (VAN BOST; MAINIL, 2003).

\section{Exotoxins}

Exotoxins are cytotoxins eliminated by E. coli strains in the enteric and extra-enteric environment. Hemolysins, cytotoxic necrosis factor (CNF), ETEC LT and ST toxins, and Shiga toxin are well-known exotoxins.

\section{Hemolysins}

Hemolysins ( $h l y$ gene) are exotoxins constituted by single chains of polypeptides; they are named because of their action on red blood cells. They form pores in the membrane of the target cells, causing cellular lysis. The iron released is then used in bacterial metabolism (BHAKDI et al., 1996; PINZÓN-SÁNCHEZ; RUEGG, 2011).

\section{CNF}

CNF, encoded by the cnf gene, is a natural protein that binds to the cellular receptor, causing intense reorganization of the actin cytoskeleton, inducing necrosis in the host tissue. CNF 1, 2, and 3 are well-known VF (VAN BOST; MAINIL, 2003). CNF has been identified in enteric as well as extraenteric infections, in particular those involving the human genitourinary tract (TÓTH et al., 2003). In cattle, it has been described in animals with and without the signs of enteritis and in cases of mastitis (KAIPAINEN et al., 2002; RIBEIRO et al., 2006).

\section{Shiga toxin}

This toxin is named "Shiga" toxin because of the structural and biological similarity with the toxin produced by Shigella dysenteriae type 1 . Previously, it was called verotoxin because of its irreversible cytopathic effect on Vero cells (African green monkey kidney cells). Since 1980, shiga toxin-producing strains have been implicated in cases of hemorrhagic colitis and hemolytic uremic syndrome in humans (TARR et al., 2005), which can causes fatal acute renal failure in children worldwide (WILLIAMS et al., 2002).

Although STEC isolates belong to different serotypes and can cause human disease, $\mathrm{O} 157: \mathrm{H} 7$ is the main-serotype observed globaly. It, indeed, has historically been commonly associated with large foodborne outbreaks (TARR et al., 2005). Despite the fact that cattle are the main reservoir of STEC, particularly serotype O157:H7, STEC isolates have also been found in the gastrointestinal tract of other domestic animals such as sheep, pigs, goats, dogs, and cats (CAPRIOLI et al., 1993). In addition, other STEC non-O157:H7 isolates have been reported as the common cause of hemolytic uremic syndrome in countries such as Australia, Germany, and Austria (GERBER et al., 2002).

\section{Serum resistance}

The ability of bacteria to survive the action of host defense mechanisms can be attributed to components such as capsular polysaccharides, plasmids (colV), surface proteins, and side chains of the $\mathrm{O}$ antigen, which probably provide protection against the lytic host complement system (PINZÓNSÁNCHEZ; RUEGG, 2011).

Resistance to serum is a common VF found in coliforms, although it is not indispensable for pathogenicity. Serum bactericidal activity is related to the action of the complement system, whose activity is reduced in the presence of milk, favoring infections during lactation (HOGAN; SMITH, 2003). 


\section{Invasins}

Invasins are VF involved in E. coli infections among domestic animals, although not fully understood. These comprise protein filaments on the bacterial surface that alter the structure of the cytoskeleton of the target cell. These structures protrude from the plasma membrane and eventually involve the microorganism, allowing the bacteria to enter the cell. Invasin genes such as ibe10 (HUANG et al., 1995) and ompA (EWERS et al., 2007) are related to the pathogenicity of $E$. coli in human vascular epithelial cells, urinary tract infections, and avian meningitis.

\section{Bovine Mastitis Caused by $\boldsymbol{E}$. coli}

Escherichia coli (E. coli) belongs to the Enterobacteriaceae family. It is a Gram-negative coccobacillus, facultatively anaerobic in nature, and belongs to the enteric microflora of most mammals. Some isolates are pathogenic to both humans and animals. The pathogenicity of this microorganism is closely related to the wide diversity of VF, which promotes the establishment of intestinal or extraintestinal infections (CROXEN; FINLAY, 2010).

E. coli is a normal inhabitant of the intestines of most animals, including humans. It is also widely found in the cow's environment. This microorganism is the causal agent of bovine mastitis, which infects the mammary gland by invading the teat canal. $E$. coli VF allow invasion and colonization in the host and evasion of host defense mechanisms and cause injury to the tissue, stimulating the local or systemic inflammatory responses (KAIPAINEN et al., 2002).

$E$. coli is the main agent with environmental origin causing clinical mastitis in dairy cattle. The cases are predominantly acute, 10-30-days long. Infections are most common during the early and late stages of the dry period, and within the first 8 weeks of lactation. However, one or more cases may occur throughout lactation (BURVENICH et al., 2003).
Since 1970s, studies have focused on the dynamics of intramammary infections caused by $E$. coli in dairy cows. Linton et al. (1979) studied the major E. coli serogroups involved in bovine mastitis and reported low specificity of the serogroups in mammary gland infections. It was earlier believed that the E. coli strains isolated from mastitis cases were essentially opportunistic (NEMETH et al., 1994). Subsequently, it was shown that $E$. coli can invade mammary tissue cells, and that the isolates associated with recurrent mastitis present greater in vitro hability and invasiveness (DÖPFER et al., 2000).

Other studies attempted to elucidate the difference in the virulence of $E$. coli strains isolated from the cow's environment compared to those isolated from mastitis cases. It was noted that $E$. coli strains isolated from mastitis cases have the ability to multiply faster (reaching high counts), compared to the environmental strains. In addition, E. coli isolates obtained from cows with mastitis showed less adhesion and were phagocytosed less actively by neutrophils, indicating that these strains are better adapted to multiply in the mammary gland (SUOJALA et al., 2011).

Various studies have been conducted since early 1980s, investigating enteric and extra-enteric VF in clinical bovine mastitis isolates (BARROW; HILL, 1989; STEPHAN; KUHN, 1999) (Table 1).

Many studies have focused on the role of $E$. coli in mastitis, the serogroups or serotypes, profile of specific virulence factors or genes, and occurrence of clinical or subclinical mastitis in dairy cows (RIBEIRO et al., 2006; WENZ et al., 2006); as opposed their relationship with the severity of clinical signs were not fully established. Clinical or systemic manifestations in mastitis have been attributed, in part, to the pathogenic action of the LPS of E. coli cell membrane. Release of the lipid fraction following phagocytosis or bacterial death in the mammary gland induces local clinical reactions and signs of endotoxic shock due to the release of 
potent cytokines and pro-inflammatory substances (RAETZ; WHITFIELD, 2002).

Reduced immune response or the opportunistic behavior of the agent has been related to the occurrence of clinical mastitis due to E. coli (BURVENICH et al., 2003; SUOJALA et al., 2011). Burvenich et al. (2003) suggested that the severity of $E$. coli mastitis cases is mainly determined by the factors related to cattle, instead the pathogenicity of the microorganism. Thus, the cow's immune response would be the critical factor influencing the development of cases. Among the host-related factors, the ability of neutrophils to phagocytose pathogens, milk production (high yielding cows are more susceptible to infections by environmental pathogens), and animal hygiene have been investigated. One of the factors that could explain the higher occurrence of severe cases at the beginning of the lactation period is the negative energy balance of the cows during the postpartum period and the reduced recruitment of leukocytes to the mammary gland during the first few days after delivery (SHUSTER et al., 1991).

Table 1. Virulence factors of $E$. coli involved in bovine clinical mastitis cases worldwide.

\begin{tabular}{|c|c|c|c|c|}
\hline VF investigated & VF detected & Country & $\mathrm{n}$ & Reference \\
\hline $\begin{array}{l}\text { Production of Shiga toxin, } \\
\text { ColV, serum resistance, } \\
\text { enterotoxins, hemolysin }\end{array}$ & $\begin{array}{l}\text { Hemolysin }(5.0 \%) \text {, Shiga toxin }(0.5 \%) \text {, entero- } \\
\text { toxins }(1.0 \%) \text {, ColV }(18.0 \%) \text {, serum resistance } \\
\qquad(23.0 \%)\end{array}$ & $\begin{array}{l}\text { England } \\
\text { and Wales }\end{array}$ & 237 & $\begin{array}{l}\text { (BARROW; } \\
\text { HILL, 1989) }\end{array}$ \\
\hline $\operatorname{trat} T, \mathrm{~K} 1$, serum resistance & $\begin{array}{c}\text { Serum resistance (64\%), tratT }(43.0 \%), \mathrm{K} 1 \\
(3.2 \%)\end{array}$ & Canada & 95 & $\begin{array}{l}\text { (NEMETH } \\
\text { et al., 1994) }\end{array}$ \\
\hline $\begin{array}{c}\text { F-17, CNF1, CNF2, LT, ST, } \\
\text { VT }\end{array}$ & F17 (51.0\%), CNF1 (5.0\%) & $\begin{array}{l}\text { Nether- } \\
\text { lands }\end{array}$ & 22 & $\begin{array}{l}\text { (LIPMAN et } \\
\text { al., 1995) }\end{array}$ \\
\hline $\begin{array}{l}\text { F17, cnfl, cnf 2, fímbriae } \\
\text { P, aerobactin, trat } T \text {, cs31A, } \\
\text { Afa family afimbrial ad- } \\
\text { hesins }\end{array}$ & $\begin{array}{c}\text { Finland: tratT }(37.0 \%), \text { cnf2 }(14.0 \%), \text { aer } \\
(11.0 \%), f 17(9.0 \%), \text { sfa }(8.0 \%), \text { cnfl }(8.0 \%), \\
\text { pap }(7.0 \%) \text {, afa } \mathrm{D}(1.0 \%), \text { afa } 8 E(1.0 \%) \\
\text { Israel: } \operatorname{tratT}(41.0 \%), \text { aer }(3.0 \%), \text { cnf } 2(2.0 \%), \\
\text { cnfl }(1.0 \%), \text { sfa }(1.0 \%), f 17(1.0 \%)\end{array}$ & $\begin{array}{c}\text { Finland } \\
\text { Israel }\end{array}$ & $\begin{array}{l}160 \\
113\end{array}$ & $\begin{array}{l}\text { (KAIPAI- } \\
\text { NEN et al., } \\
\text { 2002) }\end{array}$ \\
\hline $\begin{array}{l}\text { cnfl, cnf2, eaeA, aegg, einv, } \\
\text { etx1, stx1, stx2, vt2e, H7 }\end{array}$ & $\begin{array}{c}\operatorname{cnf2}(7.5 \%), \text { eaeA }(4.0 \%), \text { stxl }(31.0 \%), v t 2 e \\
(6.2 \%), \mathrm{H} 7(1.2 \%)\end{array}$ & $\begin{array}{l}\text { New Zea- } \\
\text { land }\end{array}$ & 80 & $\begin{array}{l}\text { (GÜLER; } \\
\text { GÜNDÜZ, } \\
\text { 2007) }\end{array}$ \\
\hline eaeA, cnfl, chf $2, \operatorname{cs} 31 A$ & $\operatorname{cnf} 2(9.8 \%), \operatorname{cnf} 1(1.6 \%), \operatorname{cs} 31 \mathrm{~A}(0.8 \%)$ & USA & 123 & $\begin{array}{l}\text { (WENZ et } \\
\text { al., 2006) }\end{array}$ \\
\hline $\begin{array}{l}\text { Siderophores, alfa-hemoly- } \\
\text { sins, STa, CNF1, VT }\end{array}$ & $\begin{array}{c}\text { Siderophores }(9.2 \%) \text {, alfa-hemolysins }(6.7 \%) \text {, } \\
\text { VT }(4.2 \%), \text { STa }(1,7 \%), \text { CNF1 }(0.8 \%)\end{array}$ & Brazil & 120 & $\begin{array}{l}\text { (RIBEIRO et } \\
\text { al., 2006) }\end{array}$ \\
\hline $\begin{array}{l}\text { Stx1, Stx2, eaeA, sta, F41, } \\
\text { K99, F17 }\end{array}$ & F17 (9.0\%), eaeA (1.0\%) & Turkey & 100 & $\begin{array}{c}\text { (MOMTAZ, } \\
2010)\end{array}$ \\
\hline $\begin{array}{c}\text { Stx1, Stx2, eaeA, sta, K99, } \\
F 41\end{array}$ & $\begin{array}{c}\text { stxl }(23.8 \%), \text { stx2 }(23.8 \%), \text { eaeA }(33.3 \%), \mathrm{F} 41 \\
(9.5 \%)\end{array}$ & Iran & 42 & $\begin{array}{l}\text { (MOMTAZ } \\
\text { et al., 2012) }\end{array}$ \\
\hline $\begin{array}{l}\text { Cva, vat, tsh, iucD, papC, } \\
\text { irp2, iss, ast } A, \text { stxl, stx2, } \\
\text { eaeA, ehxA, saa, sfaD, } \\
\quad \text { f17A, afasE, cnf } 2\end{array}$ & $\begin{array}{c}\text { irp2 }(26.4 \%), \text { iucD }(16.7 \%), \text { papC }(16.7 \%), \text { iss } \\
(16.7 \%), \text { cva }(9.7 \%), \text { AFA8 }(7.6 \%), \text { ast }(6.3 \%), \\
\text { F17 }(4.2 \%), \text { cnf } 2(2.1 \%) \text {, eaeA }(2.1 \%), \text { vat } \\
(1.4 \%), \text { sfaD }(1.4 \%), \text { tsh }(0.7 \%), \text { saa }(0.7 \%)\end{array}$ & Finland & 154 & $\begin{array}{l}\text { (SUOJALA } \\
\text { et al., 2011) }\end{array}$ \\
\hline
\end{tabular}


continuation

\begin{tabular}{|c|c|c|c|c|}
\hline $\begin{array}{l}\text { fimH, f5, f41, cs } 31 \mathrm{a}, \mathrm{f} 17 \text {, } \\
\text { f165, eae, pap, afa,sfa,sta, } \\
\text { stb, lt1, lt2, east } 1, v t 1, v t 2 \text {, } \\
\text { cnf, dldt, hly, kps, iucD }\end{array}$ & $v t 2(7.5 \%)$, fimH $(22.2 \%)$ & Brazil & 27 & $\begin{array}{l}\text { (FER- } \\
\text { NANDES et } \\
\text { al., 2011) }\end{array}$ \\
\hline Stx1, Stx2, eaeA, ehly & $\begin{array}{c}\text { Stxl }(14.5 \%), \text { stx2 }(1.9 \%), \text { eaeA }(11.6 \%), \text { ehly } \\
(4.1 \%)\end{array}$ & Iran & 73 & $\begin{array}{l}\text { (LIU et al., } \\
\text { 2014) }\end{array}$ \\
\hline $\begin{array}{c}\text { F17A, irp2, astA, iucD, } \\
\text { colV, papC, sfaD, saa, eaeA, } \\
\text { iss, ehxA, stxl, stx2 }\end{array}$ & $\begin{array}{c}\text { F17A }(15.7 \%), \text { irp2 }(14.3 \%), \text { astA }(10.0 \%), \text { iucD } \\
(7.1 \%), \operatorname{colV}(5.7 \%)\end{array}$ & China & 70 & $\begin{array}{l}\text { (LIU et al., } \\
\text { 2014) }\end{array}$ \\
\hline $\begin{array}{l}\text { kpsMTll, iucD, papA, papC } \\
\text { sfaDE, afaBC }\end{array}$ & $\begin{array}{c}\text { kpsMTll }(12.0 \%), \text { iucD }(8.0 \%), \text { papA }(1.0 \%), \\
\text { papC }(1.0 \%)\end{array}$ & Brazil & 50 & $\begin{array}{l}\text { (GUERRA } \\
\text { et al., 2019) }\end{array}$ \\
\hline
\end{tabular}

$\mathrm{VF}=$ virulence factor; $\mathrm{n}=$ number of animals.

Few studies have discussed the severity of the clinical signs of mastitis caused by E. coli and the presence of VF. In this context, Wenz et al. (2006) did not identify any association between the severity of clinical mastitis and the presence of genes encoding a specific virulence properties. Studies that investigated the genes and VF associated with the occurrence of enteric infections (LIPMAN et al., 1995; KAIPAINEN et al., 2002) found that these strains probably have little or no pathogenic action in the mammary gland of dairy cows.

\section{E. coli VF Involved in Bovine Mastitis in Brazil}

Few studies conducted in Brazil investigated the VF in the E. coli strains involved in mastitis, involving a large number of strains (RIBEIRO et al., 2006) or clonal profiles. Corrêa and Marin (2002) reported that $77.5 \%(\mathrm{n}=141 / 182) E$. coli isolates obtained from bovine mastitis cases belonged to the EPEC pathotype. Based on phenotypic assays, 120 E. coli strains recovered from 80 clinical cases and 40 subclinical mastitis cases in dairy cows from the State of São Paulo revealed presence of siderophores (9.2\%), $\alpha$-hemolysins (6.7\%), VT (4.2\%), STa (1.7\%), and CNF1 (0.8\%) (RIBEIRO et al., 2006).
In 2011, Fernandes et al. (2011) investigated differents virulence properties involved in the $E$. coli isolates obtained from the cows suffering from clinical mastitis in the region of Viçosa and Juiz de Fora, MG. In this study the genes encoding $\mathrm{VF}$ for the presence of colonization factors were fim $\mathrm{H}, f 5, f 41, \operatorname{cs} 31 a, f 17, f 165$, eae, pap, afa, and $s f a$; genes encoding exotoxins production were sta, stb, lt1, lt2, east1, stx1, stx2, cnf, cdt, and hly; gene involved in serum resistance was $\mathrm{kps}$; genes enconding siderophore production was iucD; and determination of the phylogenetic group. The virulence genes included stx2 (7.5\%) and fimH (22.2\%). Of all isolates, 29.6\% showed an association of $\mathrm{fimH}$ with $s t b$. About 15 isolates were resistant to serum. Phylogenetic classification showed that the strains belonged to groups $\mathrm{A}$ and B1, showing poor evidence of the pathogenicity of these isolates.

Recently, Guerra et al. (2019) investigated six genes (papA, papC, afaC, sfaDE, kpsMTll and $i u c D)$ in $50 \mathrm{E}$. coli isolates from clinical mastitis and detected prevalence of $\mathrm{kpsMTll}(12.0 \%)$, followed by iucD (8.0\%), papA (1.0\%) and papC (1.0\%).

Overall, the pathogenic effect of different $E$. coli VF related to bovine mastitis, mainly in the ExPEC strains, and the influence of these virulence mechanisms on clinical severity remain unclear. 
However, comparison of the genotypic profile of E. coli isolates may help understand the diversity of the clonal groups and the specific VF markers, the differences in host susceptibility, and the establishment of clinical severity.

\section{Final Considerations}

Although E. coli is considered the main etiological agent involved in the occurrence of clinical mastitis in dairy cattle, major virulence factors of this pathogen directly related to mammary infections, particularly ExPEC at different severity scores, is yet poorly understood.

Identification of the predominant VF involved in clinical mastitis in cows will contribute understand clonal variability, differences in geographical distribution, and pathogenicity of the isolates, as well as establish the prognosis at different levels of clinical severity.

\section{Conflicts of Interest}

The authors declaring have any conflicts of interest.

\section{References}

ANDERSON, G. G.; PALERMO, J. J.; SCHILLING, J. D.; ROTH, R.; HEUSER, J.; HULTGREN, S. J. Intracellular bacterial biofilm-like pods in urinary tract infections. Science, Washington, DC, v. 301, n. 5629, p. 105-107, 2003. DOI: $10.1126 /$ science. 1084550

BARROW, P. A.; HILL, A. W. The virulence characteristics of strains of Escherichia coli isolated from cases of bovine mastitis in England and Wales. Veterinary Microbiology, Barcelona, v. 20, n. 1, p. 35-48, 1989. DOI: 10.1016/0378-1135(89)90005-9

BHAKDI, S.; BAYLEY, H.; VALEVA, A.; WALEV, I.; WALKER, B.; WELLER, U.; KEHOE, M.; PALMER, M. Staphylococcal alpha-toxin, streptolysin-O, and Escherichia coli hemolysin: prototypes of poreforming bacterial cytolysins. Archives of Microbiology, Heidelberg, v. 165 , n. 2, p. $75-79$, 1996. DOI: $10.1007 /$ s002030050
BIAN, Z.; BRAUNER, A.; NORMARK, S. Expression of and cytokine activation by Escherichia coli curli fibers in human sepsis. Journal of Infectious Diseases, Oxford, v. 181 , n. 2 , p. $602-612$, 2000. DOI: $10.1086 / 315233$

BRADLEY, A. J. Bovine mastitis: an envolving disease. The Veterinary Journal, Bristol, v. 164, n. 2, p. 116-128, 2002. DOI: $10.1053 /$ tvj1.2002.0724

BURVENICH, C.; VAN MERRIS, V.; MEHRZAD, J.; DIEZ-FRAILE, A.; DUCHATEAU, L. Severity of E. coli mastites is mainly determined by cow factors. Veterinary Reserch, Ohio, v. 35, n. 5, p. 521-564, 2003. DOI: $10.1051 /$ vetres.2003023

CAPRIOLI, A.; NIGRELLI, A.; GATTI, R.; ZAVANELLA, M.; BLANDO, A. M.; MINELLI, F.; DONELLI, G. Characterisation of verocytotoxinproducing Escherichia coli isolated from pigs and cattle in northern Italy. Veterinary Record, London, v. 133, n. 13, p. 323-324, 1993. PMID: 8236671.

CHAHALES, P.; THANASSI, D. G. Structure, function, and assembly of adhesive organelles by uropathogenic bacteria. Microbiology Spectrum, Bethesda, v. 3, n. 5, p. 1-68, 2016. DOI: 10.1128/microbiolspec.UTI-00182013

CLERMONT, O.; BONACORSI, S.; BINGEN, E. Rapid and simple determination of the Escherichia coli phylogenetic group. Applied and Environmental Microbiology, Washington, v. 66, n. 10, p. 4555-4558, 2000. DOI: 10.1128/AEM.66.10.4555-4558.2000

CLERMONT, O.; CHRISTENSON, J. K.; DENAMUR, E.; GORDON, D. M. The Clermont Escherichia coli phylo-typing method revisited: improvement of specificity and detection of new phylo-groups. Environmental Microbiology Reports, London, v. 5, n. 5, p. 58-65, 2013. DOI: 10.1111/1758-2229.12019.

CORRÊA, M. G. P.; MARIN, J. M. O-serogroups, eae gene and EAF plasmid in Escherichia coli isolates from cases of bovine mastitis in Brazil. Veterinary Microbiology, Barcelona, v. 85, n. 2, p. 125-132, 2002. DOI: $10.1016 / \mathrm{S} 0378-1135(01) 00413-8$

CROXEN, M. A.; FINLAY, B. B. Molecular mechanisms of Escherichia coli pathogenicity. Nature Reviews Microbiology, London, v. 8, n. 1, p. 26-38, 2010. DOI: 10.1038/nrmicro2265

DÖPFER, D.; ALMEIDA, R. A.; LAM, T. J. G. M.; NEDERBRAGT, H.; OLIVER, S. P.; GAASTRA, W. Adhesion and invasion of Escherichia coli from single and recurrent clinical cases of bovine mastitis in vitro. Veterinary Microbiology, Barcelona, v. 74, n. 4, p. 331343, 2000. DOI: 10.1016/S0378-1135(00)00191-7 
EWERS, C.; LI, G.; WILKING, H.; KIEBLING, S.; ALT, K.; ANTÁO, E. M.; LATURNUS, C.; DIEHL, I.; GLODDE, S.; HOMEIER, T.; BÖHNKE, U.; STEINRÜCK, H.; PHILIPP, H-C.; WIELER, L. H. Avian pathogenic, uropathogenic, and newborn meningitiscausing Escherichia coli: how closely related are they? International Journal of Medical Microbiology, Berlin, v. 297, n. 3, p. 163-176, 2007. DOI: $10.1016 /$ j. ijmm.2007.01.003

FERNANDES, J. B. C.; ZANARDO, L. G.; GALVÃO, N. N.; CARVALHO, I. A.; NERO, L. A.; MOREIRA, M. A. S. Escherichia coli from clinical mastitis serotypes and virulence factors. Journal of Veterinary Diagnostic Investigation, Ontario, v. 23, n. 6, p. 1146-1152, 2011. DOI: $10.1177 / 1040638711425581$

GERBER, A.; KARCH, H.; ALLERBERGER, F.; VERWEYEN, H. M.; ZIMMERHACKL, L. B. Clinical course and the role of Shiga toxin producing Escherichia coli infection in the hemolytic-uremic syndrome in pediatric patients, 1997-2000, in Germany and Austria: a prospective study. Journal of Infectious Diseases, Oxford, v. 186 , n. 4, p. $493-500$, 2002. DOI: $10.1086 / 341940$

GUERRA, S. T.; DALANEZI, F. M.; PAULA, C. L. de; HERNANDES, R. T.; PANTOJA, J. C. F. P.; LISTONI, F. P.; LANGONI, H.; RIBEIRO, M. G. Putative virulence factors of extra-intestinal Escherichia coli isolated from bovine mastitis with different clinical scores. Letters in Applied Microbiology, Cardiff, v. 68, v.68, n. 5, p. 403408, 2019. DOI: 10.1111/lam.13113

GÜLER, L.; GÜNDÜZ, K. Virulence properties of Escherichia coli isolated from clinical bovine mastitis. Turkish Journal of Veterinary and Animal Sciences, Akai Cadessi, v. 31, n. 5, p. 361-365, 2007.

HAHN, E.; WILD, P.; HERMANNS, U.; SEBBEL, P.; GLOCKSHUBER, R.; HÄNER, M.; TASCHNER, N.; BURKHARD, P.; AEBI, U.; MÜLLER, S. A. Exploring the 3D molecular archicture of Escherichia coli type 1 pili. Journal of Molecular Biology, Free acess online, v. 323 , n. 5, p. $845-857,2002$. DOI: $10.1016 /$ S00222836(02)01005-7

HANTKE, K.; NICHOLSON, G.; RABSCH, W.; WINKELMANN, G. Salmochelins, siderophores of Salmonella entérica and uropathogenic Escherichia coli strains, are recognized by the outer membrane receptor IroN. Proceedings of National Academy of Sciences, Berkeley, v. 100, n. 7, p. 3677-3682, 2003. DOI: 10.1073/ pnas. 0737682100

HENDERSON, I. R.; NATARO, J. P. Virulence functions of autotransporter proteins. Infection and Immunity, Washington, v. 69 , n. 3, p. 1231-1243, 2001. DOI: 10.1128/IAI.69.3.1231-1243.2001
HOGAN, J.; SMITH, K. L. Coliform mastitis. Veterinary Research, Ohio, v. 34, n. 5, p. 507-519, 2003. DOI: 10.1051/vetres:2003022

HUANG, S. H.; WASS, C.; FU, Q.; PRASADARAO, N. V.; STINS, M.; KIM, K. S. Escherichia coli invasion of brain microvascular endothelial cells in vitro and in vivo: molecular cloning and characterization of invasion gene ibe10. Infection and Immunity, Washington, v. 63, n. 11, p. 4470-4475, 1995.

JOHNSON, J. R.; MURRAY, A. C.; GAJEWSKI, A.; SULLIVAN, M.; SNIPPES, P.; KUSKOWSKI, M. A.; SMITH, K. E. Isolation and molecular characterization of Nalidixic acid-resistant extraintestinal pathogenic Escherichia coli from retail chicken products. Antimicrobial Agents and Chemotherapy, Washington, v. 47, n. 7, p. $2161-2168,2003$. DOI: 10.1128/ AAC.47.7.2161-2168.2003

JOHNSON, J. R.; RUSSO, T. A.; TARR, P. I.; CARLINO, U.; BILGE, S. S.; VARY, J. C. Molecular epidemiological and phylogenetic associations of two novel putative virulence genes, iha and iroN (E. coli), among Escherichia coli isolates from patients with urosepsis. Infection and Immunity, Washington, v. 68, n. 5 , p. $3040-3047$, 2000. DOI: 10.1128/IAI.68.5.30403047.2000

KAIPAINEN, T.; POHJANVIRTA, T.; SHPIGEL, N. Y. Virulence factors of Escherichia coli isolated from bovine clinical mastitis. Veterinary Microbiology, Barcelona, v. 85 , n. 1, p. 37-46, 2002. DOI: 10.1016/ S0378-1135(01)00483-7

KAPER, J. B.; NATARO, J. P.; MOBLEY, H. L. T. Pathogenic Escherichia coli. Nature Reviews Microbiology, v. 2, n. 2, p. 123-140, 2004. DOI: 10.1038/ nrmicro818

KJAERGAARD, K.; HASMAN, H.; SCHEMBRI, M. A.; KLEMM, P. Antigen 43-mediated autotransporter display, a versatile bacterial cell surface presentation system. Journal of Bacteriology, Washington, v. 184, n. 15 , p. 4197-4204, 2002. DOI: 10.1128/JB.184.15.41974204.2002

KLEMM, P.; HANCOCK, V.; SCHEMBRI, M. A. Fimbrial adhesins from extraintestinal Escherichia coli. Environmental Microbiology Reports, London, v. 2 , n. 5 , p. $628-640,2010$. DOI: $10.1111 /$ j. 1758 2229.2010.00166.x

KLEMM, P.; SCHEMBRI, M. A. Bacterial adhesins: function and structure. International Journal of Medical Microbiology, Amsterdã, v. 290, n. 1, p. 27-35, 2000. DOI: $10.1016 / \mathrm{S} 1438-4221(00) 80102-2$

KLEMM, P.; SCHEMBRI, M. Type 1 fimbriae, curli, 
and antigen 43: adhesion, colonization, and biofilm formation. EcoSal Plus, Cambridge, v. 1, n. 1, p. 1-18, 2004. DOI: 10.1128/ecosalplus.8.3.2.6

KLINE, K. A.; FÄLKER, S.; DAHLBERG, S.; NORMARK, S.; HENRIQUES-NORMARK, B. Bacterial adhesins in host-microbe interaction. Cell Host \& Microbe, Amsterdã, v. 5, n. 6, p. 580-592, 2009. DOI: 10.1016/j.chom.2009.05.011

KÖHLER, C.; DOBRINDT, U. What defines extraintestinal pathogenic Escherichia coli? International Journal of Medical Microbiology, Amsterdã, v. 301, n.8, p. 642-647, 2011. DOI: 10.1016/j.ijmm.2011.09.006

KÖSTER, W. ABC transporter-mediated uptake of iron, siderophores, heme and vitamin B 12. Research in Microbiology, Amsterdã, v. 152, n. 3-4, p. 291-301, 2001. DOI: 10.1016/S0923-2508(01)01200-1

LE BOUGUÉNEC, C. Adhesins and invasins of pathogenic Escherichia coli. International Journal of Medical Microbiology, Amsterdã, v. 295, n. 6, p. 471478, 2005. DOI: 10.1016/1.ijmm.2005.07.001

LINTON, A. H.; HOWE, K.; SOJKA, W. J.; MAFF, C. W. A note on the range of Escherichia coli O-serotypes causing clinical bovine mastitis and their antibiotic resistance spectra. Journal of Applied Bacteriology, London, v. 46, n. 3, p. 585-590, 1979. DOI: 10.1111/ j.1365-2672.1979.tb00859.x

LIPMAN, L. J. A.; NIJS, A.; GAASTRA, W. Isolation and identification of fimbriae and toxin production by Escherichia coli strains from cows with clinical mastitis. Veterinary Microbiology, Barcelona, v. 47, n. 1, p. 1-7, 1995. DOI: 10.1016/0378-1135(95)00108-M

LIU, Y.; LIU, G.; LIU, W.; LIU, Y.; ALI, T.; CHEN, W.; YIN, J.; HAN, B. Phylogenetic group, virulence factors and antimicrobial resistance of Escherichia coli associated with bovine mastitis. Research in Microbiology, Amsterdã, v. 165, n. 4, p. 273-277, 2014. DOI: 10.1016/j.resmic.2014.03.007

MOMTAZ, H. Investigation of virulence factors in Escherichia coli isolated from clinical and subclinical bovine mastitis. Bulgarian Journal of Veterinary Medicine, Stara Zagora, v. 13, n. 2, p. 122-126, 2010.

MOMTAZ, H.; DEHKORDI, F. S.; TAKTAZ, T.; REZVANI, A.; YARALI, S. Shiga toxin-producing Escherichia coli isolated from bovine mastitic milk: serogroups, virulence factors, and antibiotic resistance properties. The Scientific World Journal, New York, v. 2012, n. 1, p. 1-9, 2012. DOI: 10.1100/2012/618709

MYSOREKAR, I. U.; HULTGREN, S. J. Mechanisms of uropathogenic Escherichia coli persistence and eradication from the urinary tract. Proceedings of the
National Academy of Sciences, St. Loius, v. 103, n. 38, p. 14170-14175, 2006. DOI: 10.1073/pnas.0602136103

NEMETH, J.; MUCKLE, C. A.; GYLES, C. L. In vitro comparison of bovine mastitis and fecal Escherichia coli isolates. Veterinary Microbiology, Barcelona, v. 40, n. 3, p. 231-238, 1994. DOI: 10.1016/0378-1135(94)90112-0

OLIVEIRA, C. S. F.; HOGVEEN, H.; BOTELHO, A. M.; MAIA, P. V.; COELHO, S. G.; HADDAD, J. P. A. Cow-specific risk factors for clinical mastitis in Brazilian dairy cattle. Preventive Veterinary Medicine, Colorado, v. 121, n. 3-4, p. 297-305, 2015. DOI: 1o.1016/j. prevetmed.2015.08.001

PINZÓN-SÁNCHEZ, C.; RUEGG, P. L. Risk factors associated with short-term post-treatment outcomes of clinical mastitis. Journal of Dairy Science, Champaign, v. 94 , n. 7 , p. $3397-3410$, 2011. DOI: $10.3168 /$ jds.20103925

PRASADARAO, N. V.; WASS, C. A.; HACKER, J.; JANN, K.; KIN, K. S. Adhesion of S-fimbriated Escherichia coli to brain glycolipids mediated by $s f a A$ gene-encoded protein of S-fimbriae. The Journal of Biological Chemistry, Maryland, v. 268, n. 14, p. 1035610363, 1993.

PROFT, T.; BAKER, E. N. Pili in Gram-negative and Gram-positive bacteria-structure, assembly and their role in disease. Cellular and Molecular Life Sciences, Heidelberg, v. 66, n. 4, p. 613-635, 2009. DOI: 10.1007/ s00018-008-8477-4

PROVENCE, D. L.; CURTISS, R. Role of crl in avian pathogenic Escherichia coli: a knockout mutation of crl does not affect hemagglutination activity, fibronectin binding, or curli production. Infection and Immunity, Washington, v. 60, n. 11, p. 4460-4467, 1992.

RAETZ, C. R. H.; WHITFIELD, C. Lipopolysaccharide Endotoxins. Annual Review of Biochemistry, Palo Alto, v. 71, n. 1, p. 635-700, 2002. DOI: 10.1146/annurev. biochem.71.110601.135414

RIBEIRO, M. G.; COSTA, E. O.; LEITE, D. S.; LANGONI, H.; GARINO JÚNIOR, F.; VICTÓRIA, C.; LISTONI, F. J. P. Fatores de virulência em linhagens de Escherichia coli isoladas de mastite bovina. Arquivo Brasileiro de Medicina Veterinária e Zootecnia, Belo Horizonte, v. 58, n. 5, p. 724-731, 2006. Disponível em:http://www.scielo.br/pdf/\%0D/abmvz/v58n5/04.pdf. Acesso em: 29 maio 2019.

RIBEIRO, M. G.; LEITE, D. S.; SIQUEIRA, A. K. Enfermidades por Escherichia coli. In: MEGID, J.; RIBEIRO, M. G.; PAES, A. C. Doenças infecciosas em animais de produção e companhia. Rio de Janeiro: Roca, 2016. p. 243-273. 
RIETSCHEL, E. T.; KIRIKAE, T.; SCHADE, F. U.; MAMAT, U.; SCHMIDT, G.; LOPPNOW, H.; ULMER, A. J.; ZAHRINGER, U.; SEYDEL, U.; DI PADOVA, F. Bacterial endotoxin: molecular relationships of structure to activity and function. The FASEB Journal, Bethesda, v. 8, n. 2, p. 217-225, 1994. DOI: 10.1096/ fasebj.8.2.8119492

RODRIGUEZ-SIEK, K. E.; GIDDINGS, C. W.; DOETKOTT, C.; JOHNSON, T. J.; NOLAN, L. K. Characterizing the APEC pathotype. Veterinary Research, Ohio, v. 36, n. 2, p. 241-256, 2005. DOI:10.1051/ vetres:2004057

RUEGG, P. L. A 100-year review: mastitis detection, management, and prevention. Journal of Dairy Science, Champaign, v. 100, n. 12, p. 10381-10397, 2017. DOI: $10.3168 /$ jds.2017.13023

SCHEMBRI, M. A.; HJERRILD, L.; GJERMANSEN, M.; KLEMM, P. Differential expression of the Escherichia coli autoaggregation factor antigen 43. Journal of Bacteriology, Washington, v. 185, n. 7, p. 2236-2242, 2003. DOI: 10.1128/JB.185.7.2236-2242

SHPIGEL, N. Y.; ELAZAR, S.; ROSENSHINE, I. Mammary pathogenic Escherichia coli. Current Opinion in Microbiology, Amsterdã, v. 11, n. 1, p. 60-65, 2008. DOI: $10.1016 /$ j.mib.2008.01.004

SHUSTER, D. E.; HARMON, R. J.; JACKSON, J. A.; HEMKEN, R. W. Suppression of milk production during endotoxin-induced mastitis. Journal of Dairy Science, Champaign, v. 74 , n. 11, p. 3763-3774, 1991. DOI: 10.3168/jds.S0022-0302(91)78568-8

STEPHAN, R.; KUHN, K. Prevalence of verotoxigenicproducing Escherichia coli (VTEC) in bovine $E$. coli mastitis and their antibiotic resistance patterns. Zentralblatt Veterinarmed, Berlin, v. 46, n. 6, p. 423-427, 1999.

SUOJALA, L.; POHJANVIRTA, T.; SIMOJOKI, H.; MYLLYNIEMI, A. L.; PITKÄLÄ, A.; PELKONEN, S.; PYÖRÄLÄ, S. Phylogeny, virulence factors and antimicrobial susceptibility of Escherichia coli isolated in clinical bovine mastitis. Veterinary Microbiology, Barcelona, n. 147, n. 3-4, p. 383-388, 2011. DOI: 10.1016/j.vetmic.2010.07.011

TARR, P. I.; GORDON, C. A.; CHANDLER, W. L. Shiga-toxin-producing Escherichia coli and haemolytic uraemic syndrome. The Lancet, Amsterdã, v. 365, n. 9464, p. 1073-1086, 2005. DOI: 10.1016/S01406736(05)71144-2

TÓTH, I.; HÉRAULT, F.; BEUTIN, L.; OSWALD, E. Production of cytolethal distending toxins by pathogenic Escherichia coli strains isolated from human and animal sources: establishment of the existence of a new cdt variant (Type IV). Journal of Clinical Microbiology, Barcelona, v. 41, n. 9, p. 4285-4291, 2003. DOI: 10.1128/ JCM.41.9.4285-4291.2003

VAN BOST, S.; MAINIL, J. Facteurs de virulence et propriétés spécifiques des souches invasives d'Escherichia coli: 111) Production de toxines. Annales de Médecine Vétérinaire, Liège, v. 147, n. 1, p. 327-342, 2003. Available at: http://www.facmv.ulg.ac.be/amv/ articles/2003 147 5 03.pdf. Accessed at: 29 may 2019.

WENZ, J. R.; BARRINGTON, G. M.; GARRY, F. B.; DINSMORE, R. P.; CALLAN, R. J. Use of systemic disease signs to assess disease severity in dairy cows with acute coliform mastitis. Journal of the American Veterinary Medical Association, Schaumburg, v. 218, n. 4, p. 567-572, 2001. DOI: 10.2460/javma.2001.218.567

WENZ, J. R.; BARRINGTON, G. M.; GARRY, F. B.; ELLIS, R. P.; MAGNUSON, R. J. Escherichia coli isolates serotypes, genotypes and virulence genes and clinical coliform mastitis severity. Journal of Dairy Science, Champaign, v. 89, n. 9, p. 3408-3412, 2006. DOI: $10.3168 /$ jds.S0022-0302(06)72377-3

WILLIAMS, D. M.; SREEDHAR, S. S.; MICHELL, J. J.; CHAN, J. C. M. Acute kidney failure: a pediatric experience over 20 years. Archives of Pediatrics \& Adolescent Medicine, Chicago, v. 156, n. 9, p. 893-900, 2002. DOI: $10.1001 /$ archpedi.156.9.893 